\title{
Short Communication: Genetic diversity of Indonesian's sugarcane varieties (Saccharum officinarum) based on RAPD molecular markers
}

\author{
RINA SRI KASIAMDARI ${ }^{1}$, GANIES RIZA ARISTYA ${ }^{2, \bullet}$, HERI PRABOWO $^{3}$, CHRISTY ARIESTA $^{4}$, \\ MUHAMMAD FAUZI ARIF \\ ${ }^{1}$ Laboratory of Plant Systematics, Faculty of Biology, Universitas Gadjah Mada. Jl. Teknika Selatan, Sekip Utara, Sleman 55281, Yogyakarta, Indonesia \\ ${ }^{2}$ Laboratory of Genetics and Breeding, Faculty of Biology, Universitas Gadjah Mada. Jl. Teknika Selatan, Sekip Utara, Sleman 55281, Yogyakarta, Indonesia \\ ${ }^{3}$ Indonesian Sweetener and Fiber Crops Research Institute (ISFRI). J1. Raya Karangploso, Malang 65152, East Java, Indonesia \\ ${ }^{4}$ Faculty of Biology, Universitas Gadjah Mada. Jl. Teknika Selatan, Sekip Utara, Sleman 55281, Yogyakarta, Indonesia. Tel.: +62-274-580839, Fax.: \\ +62-274-6492355, `email: ganies_riza@ugm.ac.id
}

Manuscript received: 24 June 2019. Revision accepted: 21 September 2019.

\begin{abstract}
Kasiamdari RS, Aristya GR, Prabowo H, Ariesta C, Arif MF. 2019. Genetic diversity of Indonesian's sugarcane varieties (Saccharum officinarum) based on RAPD molecular markers. Biodiversitas 20: 3005-3010. Sugarcane (Saccharum officinarum L.) belongs to the Poaceae family which are widely used for sweeteners production. In Indonesia, the need for sugarcane continues to increase along with its increased use in the production of bioethanol from molasses, a by-product of sugar production. However, the supply for sugar is still far from enough. Improvement of sugarcane productivity can be done by selecting superior varieties to form a new superior hybrid. Maintaining high genetic diversity in a population is essential. Selection of varieties is important because it can increase productivity without increasing the cost of crop production. Even the selected pest-resistant varieties can reduce the cost of crop production. Indonesia had produced many superior sugarcane plant varieties, but studies on their characters and genetic relationship are still lacking. Several molecular markers have been used to elucidate the genetic diversity among sugarcane varieties. Random Amplified Polymorphism DNA (RAPD) is one of the molecular markers that have been proven to describe genetic diversity among sugarcane plants. This study aimed to determine the genetic diversity among 22 superior sugarcane varieties in Indonesia based on eight RAPD molecular markers. The superior sugarcane varieties in Indonesia in this study were obtained from Indonesian Sweetener and Fiber Crops Research Institute (ISFRI), Malang and Madukismo Sugar Factory, Yogyakarta. DNA products were visualized by using gel electrophoresis and resolved bands were scored as binary data as presence (1) and absence (0). Linkage distance was done based on Jaccard's similarity coefficient, and clustering analysis was performed based on the unweighted pair- group average (UPGMA) method. Polymorphism Information Content (PIC) analysis showed a high degree of polymorphism ranging from 0.76 to 0.92 . Cluster analysis showed that 22 sugarcane varieties were divided into two main clusters and four sub-clusters based on their origin.
\end{abstract}

Keywords: Clustering, genetic diversity, polymorphism, RAPD, Saccharum officinarum

\section{INTRODUCTION}

Sugarcane (Saccharum officinarum L.) belongs to the genus Saccharum, tribe Andropogonaceae of family Poaceae or Graminae (James 2004). Saccharum is a genetically complex group of crop and composed of at least six distinct species as $S$. officinarum, S. barberi, S. sinense, S. spontaneum, S. robustum, dan S. edule (James 2004; Pandey et al. 2011). Sugarcane is widely known as sweet tooth as it is used as the first sweetener in worldwide. The need for sugarcane is increasing as its growing use not only limited to sweetener but also for other purposes. Nowadays, sugarcane is also used to produce bioethanol from molasses as sugar byproduct and enrich soil organic matter (Pandey et al. 2011). In Indonesia, sugarcane is the main crop for sugar production and plays a vital economic role in Indonesian society. Although the need for sugar continues to increase, its production is still far from enough. The main problems of sugarcane productivity faced in Indonesia are pests attack and low sugar content caused by poor cultivation technique. Most farmers are more concerned with plant mass (Subiyakto et al. 2016).

Breeding is widely known as a fundamental principle to increase most sugarcane industry's productivity in the world and contributes to a high degree of genetic variety (Devarumath et al. 2012; James 2004). Selection of variety is also one of the most important factors because of its ability to increase sugarcane productivity without an increase in growing costs, and pest-resistant selected crop may even reduce growing costs (James 2004; M da Costa et al. 2011). Various efforts have been made to improve sugarcane variety. These efforts are generally divided into three stages: characterization and evaluation of germplasm, cross-pollination, and selection. The final stage of the three-stage leads to the adaptation of the individual environment (Devarumath et al. 2012; James 2004).

Indonesia has superior sugarcane varieties, but there are no studies that have examined genetic variation and relationship among them. Characterization of genetic variation is an essential step to improve the quality of sugarcane varieties (Ekpelikpeze et al. 2016). Several molecular markers proved to be useful in detecting genetic 
variation among genotypes are Random Amplified Polymorphic DNA (RAPD), Simple Sequence Repeat (SSR), Inter-Simple Sequence Repeat (ISSR), Single Nucleotide Polymorphism (SNP) and Isozymes (Devarumath et al. 2012; Ghane et al. 2017; M da Costa et al. 2011; Pandey et al. 2011). Despite concerns about its reproducibility and its utility in diversity analysis, the use of RAPD markers in plant variety selection was based on its simplicity, level of polymorphism detection, costeffectiveness, easily applicable to any plant species and target the sequences which are abundant throughout the genome and are rapidly evolved (Ghane et al. 2017).

Molecular markers are useful in evaluating and characterizing genetic variations is determined by the degree of information polymorphism. The concept of polymorphism is used as a term to describe genetic variability in a population. Polymorphism information content (PIC) is one of the parameters used to determine the degree of polymorphism of a molecular marker (Chesnokov and Artemyeva 2015). The PIC value is determined based on the ability of a molecular marker to show polymorphisms in a population. In other words, PIC identifies the discrimination ability of a molecular marker depending on the number of alleles and alleles distribution, so that it is equivalent to genetic diversity. PIC value ranges from 0 (monomorphic) to 1 (polymorphic or highly discriminatory) (Chesnokov and Artemyeva 2015; Sonarkili et al. 2017). According to the research of Botstein et al. (1980), the PIC value was classified into three categories, namely, PIC $<0.25$ (less informative), 0.25 $<$ PIC $<0.50$ (moderate informative), and PIC $>0.50$ (highly informative). The aim of this study was to elucidate genetic variation among twenty-two superior sugarcane varieties collection in Indonesia based on RAPD markers. This will then be helpful for Indonesian national breeding program to decide potential sugarcane parental crosses for the benefit of Indonesian sugar production.

\section{MATERIALS AND METHODS}

\section{Plant materials}

Twenty-two commercial varieties of sugarcane were obtained from Indonesian Sweetener and Fiber Crops Research Institute (ISFRI) in Malang and Madukismo Sugar Factory in Yogyakarta, Indonesia. Eighteen varieties (PS 41, PS 58, PS 384, PS 851, PS 862, PS 864, PS 865, PS 881, PS 891, PS 921, PS 951, PS 80.910, PS 80.1649, PS CO. 902, PS Bunga Mayang (PSBM) 901, Kidang Kencana (KK), Bululawang (BL), and Kentung) were grown in Indonesian Sweetener and Fiber Crops Research
Institute (ISFRI) in Malang, while four varieties (VMC 7616, TLH (Tolangohula) 2, BZ 132, and PSDK 923) were grown in Madukismo Sugar Factory in Yogyakarta. Most of the sugarcane germplasm were cross-bred and selected by the Indonesian Sugar Research and Development Center (P3GI). The information on their parentage and origin are shown in Table 1.

\section{Procedure}

\section{DNA isolation}

DNA was isolated from young leaves tissues of twentytwo varieties using the Nucleon Phytopure reagent kit. The kit consists of Phytopure reagent I, reagent II, and PhytoPure Resin. Each sample was weighted 0.3 grams and ground with liquid nitrogen added until formed fine powder. The fine samples were put into a 1.5 microtube and added with Phytopure I and II reagents gradually. Mixed samples were then incubated at $65^{\circ} \mathrm{C}$ for 10 minutes. The samples were incubated at $-20^{\circ} \mathrm{C}$ for 20 minutes, and then $500 \mu \mathrm{L}$ cold Chloroform solution and $70 \mu \mathrm{L}$ Phytopure Resin was added to the mixed samples. Microtubes containing sample were then centrifuged at $13.000 \mathrm{rpm}$ for 10 minutes by microcentrifugation (GyroSpin Gyrozen). The supernatant of each sample was taken and transferred to a new microtube. Supernatant was added with cold isopropanol (1:1 ratio). The sample was inverted for 8 to 10 times and precipitated for 60 minutes and then centrifuged in $10.000 \mathrm{rpm}$ for 10 minutes. The supernatant was removed and discarded by adding $100 \mu \mathrm{L}$ of $70 \%$ ethanol and centrifuged in $10.000 \mathrm{rpm}$ for 5 minutes. Supernatant added by another $70 \%$ ethanol, then centrifuged in $13.000 \mathrm{rpm}$ for 5 minutes. Pellet dissolved in $50 \mu \mathrm{L}$ of $1 \times$ buffer TE solution and stored in $-20^{\circ} \mathrm{C}$ freezer. The qualitative and quantitative genomic DNA testing was carried out to determine the success of the isolated genomic DNA. The qualitative test was determined using an electrophoresis agarose gel. Genomic DNA was separated on $0.8 \%$ horizontal agarose gel in TBE buffer with a voltage of $50 \mathrm{~V}$ for $55 \mathrm{~min}$ and visualized under ultraviolet light after staining in $0.0001 \mu \mathrm{g} / \mathrm{mL}$ FloroSafe DNA stain. Each gel photo containing PCR product was digitally documented. The $1 \mathrm{~kb}$ bp DNA ladder of Promega DNA plus molecular weight marker was used to compare the molecular weight of amplified products. The quantitative test was done by determined comparatively the genomic DNA concentrations by using a spectrophotometer (NanoVue Plus) in lambda $260 \mathrm{~nm} / 280$ $\mathrm{nm}$. Each $\lambda$ 260/280 nm absorbance showed $50 \mu \mathrm{g} / \mathrm{mL}$ of DNA concentration. The DNA concentration was measured with absorbance formula $\lambda 260 / 280 \times 50$ x dissolve $\mu \mathrm{g} / \mathrm{mL}$ (Sambrook and Russel 1989).

Table 2. List of eight RAPD primers used for DNA amplification (Ullah et al. 2013)

\begin{tabular}{lccllc}
\hline Primer & Sequence $\left(\mathbf{5}^{\prime} \mathbf{- 3}\right)$ & G+C content $(\boldsymbol{\%})$ & Primer & Sequence $\left(\mathbf{5}^{\prime}-\mathbf{3}^{\prime}\right)$ & G+C content $(\boldsymbol{\%})$ \\
\hline OPA 01 & CAGGCCCTTC & 70 & OPC 01 & TTCGAGCCAG & 60 \\
OPA 02 & TGCCGSGCTG & 70 & OPC 02 & GTGAGGCGTC & 70 \\
OPB 05 & TGCGCCCTTC & 70 & OPD 01 & ACCGCGAAGG & 70 \\
OPB 09 & TGGGGGACTC & 70 & OPD 03 & GTCGCCGTCA & 70 \\
\hline
\end{tabular}


Table 1. Parentage and origin of sixteen sugarcane varieties used in diversity analysis

\begin{tabular}{llllll}
\hline Variety & Parentage & Region of origin & Variety & Parentage & Region of origin \\
\hline PS 851 & PS 57 x B 37172 & P3GI Pasuruan, East Java & PSCO 902 & POJ 2722 (polycross) & P3GI Pasuruan, East Java \\
PS 862 & F 162 (polycross) & P3GI Pasuruan, East Java & PSBM 901 & PS 78- 127 (polycross) & P3GI Pasuruan, East Java \\
PS 864 & PR 1117 (polycross) & P3GI Pasuruan, East Java & BL & - & South Malang, East Java \\
PS 865 & POJ 4947 x POJ 2946 & P3GI Pasuruan, East Java & Kentung & - & Kediri, East Java \\
PS 881 & BQ 33 (polycross) & P3GI Pasuruan, East Java & KK & - & Kidangkencana, West Java \\
PS 891 & BR 913 x BT 5001 & P3GI Pasuruan, East Java & TLH 2 & - & Kendari, Southeast Sulawesi \\
PS 921 & BP 1854 (polycross) & P3GI Pasuruan, East Java & PSDK 923 & - & P3GI Pasuruan, East Java \\
PS 951 & BR 913 x PS 60 & P3GI Pasuruan, East Java & VMC 76- 16 & - & Philippines \\
\hline
\end{tabular}

\section{$\begin{array}{llllllllllllllllllllllll}M & 1 & 2 & 3 & 4 & 5 & 6 & 7 & 8 & 9 & 10 & 11 & 12 & 13 & 14 & 15 & 16 & 17 & 18 & 19 & 20 & 21 & 22 & M\end{array}$}

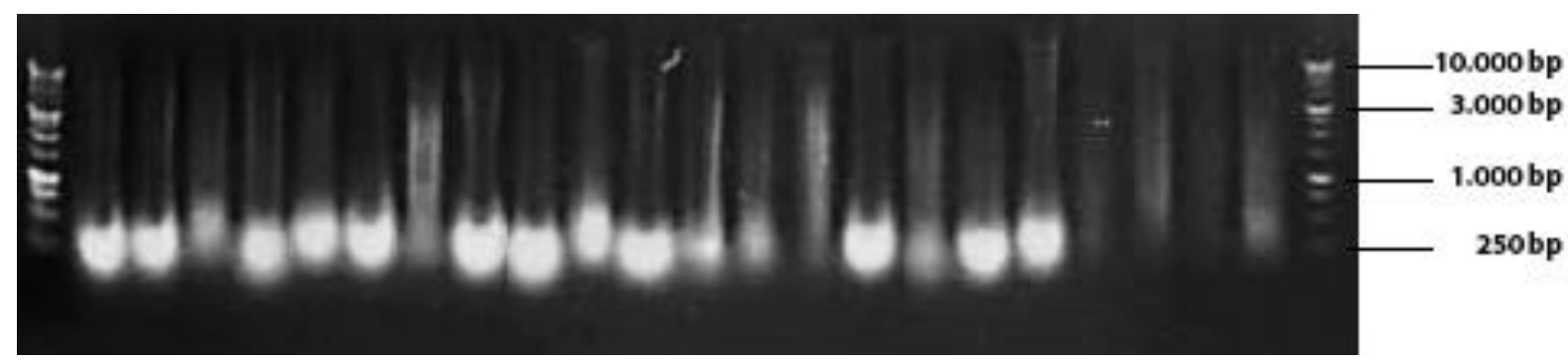

Figure 1. Electrophoregram of twenty two genomic DNA samples $(M=1 \mathrm{~kb}$ bp Promega Ladder, Lane $1=$ PS 41 , Lane $2=$ PS 58 , Lane $3=$ PS 384, Lane $4=$ PS 851 , Lane $5=$ PS 862 , Lane $6=$ PS 864, Lane $7=$ PS 865 , Lane $8=$ PS 881 , Lane $9=$ PS 891 , Lane $10=$ PS 921, Lane $11=$ PS 951, Lane $12=$ PS 80.910, Lane $13=$ PS 80.1649, Lane $14=$ PS CO. 902, Lane $15=$ PSBM 901, Lane $16=$ KK, Lane $17=$ BL, Lane 18 = Kentung, Lane $19=$ VMC 76-16, Lane $20=$ TLH 2, Lane $21=$ BZ 132, Lane $22=$ PSDK 923)

\section{PCR amplification and electrophoresis}

Eight random amplified polymorphic DNA (RAPD) markers were utilized to examine genetic diversity among 22 varieties of sugarcane (Table 2) (Ullah et al. 2013). The RAPD amplification each reaction contained $12.5 \mu \mathrm{L}$ of Bioline MyTaq HS Red Mix PCR kit, $2.0 \mu \mathrm{L}$ of RAPD primer (OPA 01, OPA 02, OPB 05, OPB 09, OPC 01, OPC 02 , OPD 01 , and OPD 03 ), $8.5 \mu \mathrm{L}$ of $\mathrm{dd}_{2} \mathrm{O}$, and $2.0 \mu \mathrm{L}$ of template DNA. The amplification reaction was carried out in a T100 Thermal Cycler BioRad. The PCR reaction included an initial denaturation step of $10 \mathrm{~min}$ at $94^{\circ} \mathrm{C}$, followed by 40 cycles, each consisted of a denaturation step of $1 \mathrm{~min}$ at $94^{\circ} \mathrm{C}$, annealing of $1 \mathrm{~min}$ at $43^{\circ} \mathrm{C}$ to $44.3^{\circ} \mathrm{C}$ (depending on the primer) and an extension of $2 \mathrm{~min}$ at $72^{\circ} \mathrm{C}$. PCR was terminated with a final extension of $10 \mathrm{~min}$ at $72^{\circ} \mathrm{C}$. RAPD products were separated on $2 \%$ horizontal agarose gel in TBE buffer with a voltage of $50 \mathrm{~V}$ for 55 min and visualized under ultraviolet light after staining in $0.0001 \mu \mathrm{g} / \mathrm{mL}$ FloroSafe DNA stain. Digital photo documentation was taken for each gel. The $100 \mathrm{bp}$ Promega DNA plus molecular weight marker was used to compare the molecular weight of amplified products.

\section{Data analysis}

Resolved bands were scored as binary data: present (1) or absent (0) using Adobe Photoshop CS6 (McDanniel and Pillai 2002). Genetic similarity was calculated based on Jaccard's Coefficient. A dendrogram was constructed to visualize the similarity using the unweighted pair-group method arithmetic average (UPGMA) performed by using
MVSP 3.1 software. Electrophoresis visualization was done by counting the total number of bands, both monomorphic and polymorphic bands, produced by eight primers in all twenty-two varieties. The degree of polymorphisms was determined using Polymorphism Information Content (PIC) value calculated by the formula of Anderson et al. (1993) as follows:

$$
P I C_{j}=1-\sum_{1=1 \text { to } L} P^{2} I j
$$

\section{RESULTS AND DISCUSSION}

\section{Quantification of genomic DNA}

The purity of isolated genomic DNA was determined by using $260 \mathrm{~nm}$ UV absorption. The results showed that the absorbance of isolated genomic DNA of twenty-two varieties ranged from 1.45 to 2.11 (Table 3). The visualization of genomic DNA was done by horizontal agarose gel electrophoresis $(0.8 \%)$ compared to known 1 $\mathrm{kb}$ molecular weight marker of Promega Ladder (Figure 1).

\section{PCR amplification and electrophoresis}

Twenty-two genomic DNA samples amplified by eight RAPD primers (Table 2) produced a total of 994 bands with an average of 117.5 bands per primer. The band size of RAPD PCR product ranged from $150 \mathrm{bp}$ to $1700 \mathrm{bp}$ (Table 4). The electrophoregrams are shown in Figure 2. 
Table 3. Spectrophotometric absorption readings and DNA concentration of twenty-two DNA genomic samples

\begin{tabular}{lccccc}
\hline Variety & $\begin{array}{c}\text { Absorbance } \\
(\mathbf{A 2 6 0 / A 2 8 0})\end{array}$ & $\begin{array}{c}\text { DNA concentration } \\
\left(\mathbf{n g} \boldsymbol{\mu \mathbf { L } ^ { - 1 } )}\right.\end{array}$ & Variety & $\begin{array}{c}\text { Absorbance } \\
(\mathbf{A 2 6 0} / \mathbf{A 2 8 0})\end{array}$ & $\begin{array}{c}\text { DNA concentration } \\
\left(\mathbf{n g} \boldsymbol{\mu L} \mathbf{L}^{-\mathbf{1}}\right)\end{array}$ \\
\hline PS 41 & 1.45 & 861.5 & PS 80.910 & 1.89 & 1707.0 \\
PS 58 & 2.04 & 785.0 & PS 80.1649 & 2.01 & 260.5 \\
PS 384 & 1.95 & 276.5 & PSCO 902 & 2.00 & 542.0 \\
PS 851 & 2.05 & 632.0 & PSBM 901 & 2.02 & 1140.0 \\
PS 862 & 2.06 & 964.0 & BL & 2.03 & 544.0 \\
PS 864 & 2.11 & 1315.0 & Kentung & 2.00 & 875.0 \\
PS 865 & 1.98 & 241.0 & BZ 132 & 1.98 & 1.60 \\
PS 881 & 2.02 & 1849.0 & TLH 2 & 1.54 & 1875.0 \\
PS 891 & 2.03 & 946.0 & PSDK 923 & 2.07 & 88.5 \\
PS 921 & 1.95 & 493.0 & VMC 76-16 & 1.66 & 76.0 \\
PS 951 & 2.00 & 1310.0 & &
\end{tabular}
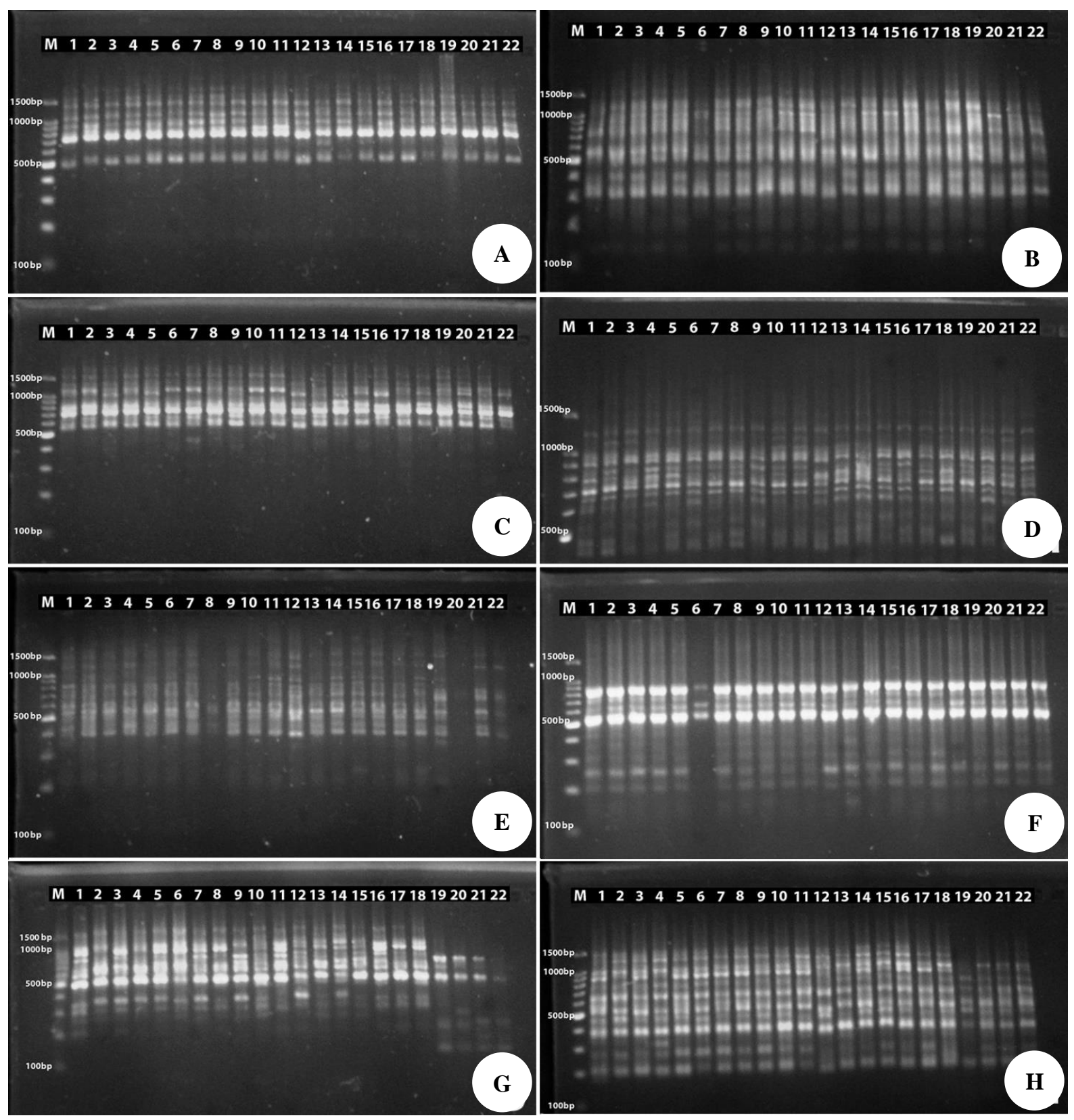

Figure 2. DNA fingerprinting of twenty two sugarcane varieties based on RAPD primers separated using a 2\% agarose gel, (a) OPA 01, (b) OPA 02, (c) OPB 05, (d) OPB 09, (e) OPC 01, (f) OPC 02, (g) OPD 01, (h) OPD 03. (Lane M= 1 kb bp Promega Ladder, Lane 1= PS 41, Lane $2=$ PS 58, Lane 3=PS 384, Lane $4=$ PS 851, Lane $5=$ PS 862, Lane $6=$ PS 864, Lane $7=$ PS 865 , Lane $8=$ PS 881 , Lane $9=$ PS 891, Lane $10=$ PS 921, Lane $11=$ PS 951, Lane $12=$ PS 80.910, Lane $13=$ PS 80.1649, Lane $14=$ PS CO. 902 , Lane $15=$ PSBM 901, Lane $16=$ KK, Lane $17=$ BL, Lane $18=$ Kentung, Lane $19=$ VMC 76-16, Lane $20=$ TLH 2, Lane $21=$ BZ 132, Lane 22= PSDK 923) 
Table 4. List of RAPD primers producing polymorphic and monomorphic bands

\begin{tabular}{|c|c|c|c|c|c|c|c|}
\hline Primer & $\begin{array}{l}\text { Band size } \\
\text { (bp) }\end{array}$ & $\begin{array}{c}\text { Total number } \\
\text { of loci }\end{array}$ & $\begin{array}{c}\text { Total } \\
\text { number of } \\
\text { bands }\end{array}$ & $\begin{array}{c}\text { Number of } \\
\text { monomorphic } \\
\text { bands }\end{array}$ & $\begin{array}{c}\text { Number of } \\
\text { polymorphic } \\
\text { bands }\end{array}$ & $\begin{array}{c}\text { Polymorphism } \\
(\%)\end{array}$ & $\begin{array}{l}\text { PIC } \\
\text { value }\end{array}$ \\
\hline OPA 01 & $550-1700$ & 12 & 118 & 2 & 10 & 83.33 & 0.80 \\
\hline OPA 02 & $290-1450$ & 14 & 105 & 0 & 14 & 100.00 & 0.88 \\
\hline OPB 05 & $470-1500$ & 11 & 103 & 1 & 10 & 90.91 & 0.81 \\
\hline OPB 09 & $340-1200$ & 25 & 157 & 1 & 24 & 96.00 & 0.91 \\
\hline OPC 01 & $350-900$ & 10 & 83 & 0 & 10 & 100.00 & 0.86 \\
\hline OPC 02 & $150-940$ & 13 & 141 & 2 & 11 & 84.62 & 0.76 \\
\hline OPD 01 & $140-1500$ & 20 & 117 & 0 & 20 & 100.00 & 0.92 \\
\hline OPD 03 & $190-1400$ & 21 & 170 & 2 & 19 & 90.48 & 0.86 \\
\hline Total & & 126 & 994 & 8 & 118 & 745.33 & 6.83 \\
\hline Average & & 13.5 & 117.5 & 1 & 12.5 & 93.45 & 0.86 \\
\hline
\end{tabular}

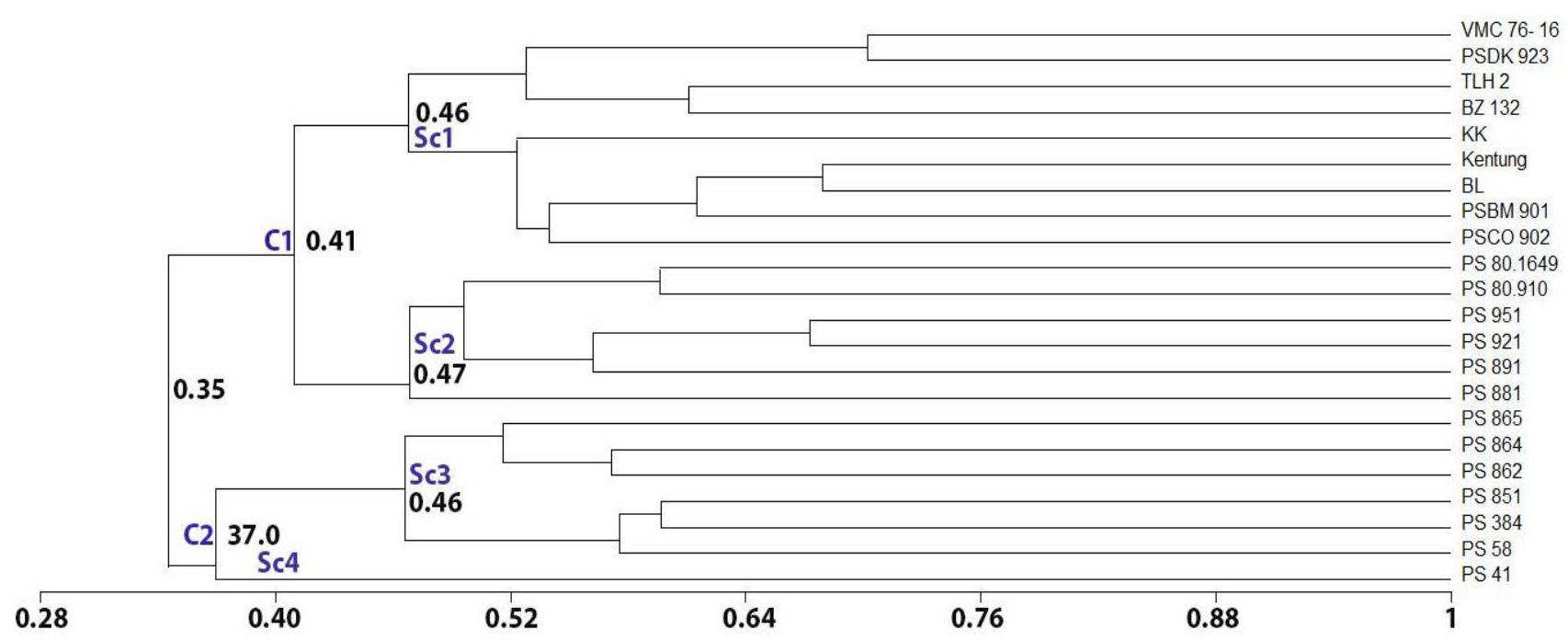

Figure 3. UPGMA cluster analysis of 22 sugarcane varieties based on RAPD markers

\section{Polymorphisms revealed by RAPD primers}

RAPD amplification products from eight primers performed on 22 sugarcane varieties showed a total of 994 bands at 126 loci; 118 were polymorphic bands and the remaining eight were monomorphic bands (Table 4). The OPA 02, OPC 01 and OPD 1 primers showed 100\% polymorphic bands. The PIC value of the eight primers ranged from 0.76 to 0.92 , which was categorized as high polymorphism level.

\section{Linkage distance and clustering analysis among twenty-} two sugarcane varieties

The linkage distance between varieties was determined based on similarity through binary data using Jaccard's similarity coefficient performed by using MVSP software version 3.2. The lowest similarity was found between PS 41 and PS 80.910 (21.8\%), while the highest similarity was found between VMC 76-16 and PSDK 923 (70.2\%). The dendrogram, as shown in Figure 3 based on linkage distance with UPGMA clustering algorithm indicated the segregation of the twenty-two varieties. Figure 3 shows that the 22 sugarcane varieties were grouped into two main clusters and four sub-clusterss. The first sub-cluster consisted of VMC 76-16, PSDK 923, TLH 2, and BZ 132. The second sub-cluster consisted of KK, Kentung, BL, PSBM 901, and PSCO 902. The third sub-cluster consisted of PSCO 80.1649, PS 80,910, PS 951, PS 921, PS 891, PS 881, PS 865, PS 864, PS 882, PS 851, PS 384, and PS 58, while PS 41 secluded from the other sub-clusters. Subclusters one and two were then combined to form cluster one, while sub-clusters three and four merged to form the second cluster.

\section{Discussion}

Quantitative and qualitative assessment of genomic DNA is the first step to determine isolated DNA quality. A good DNA purity ranges from 1.8 to 2.0 at an absorbance of $260 / 280 \mathrm{~nm}$. In this study, the purity of 22 genomic 
DNA samples at 260/280 $\mathrm{nm}$ absorbance ranged from 1.45 to 2.07. The observed variation in DNA genomic purity was probably due to the varying $\mathrm{pH}$ range. An acidic $\mathrm{pH}$ will cause a low absorbance and an alkaline $\mathrm{pH}$ can cause a higher absorbance (William et al. 1997). PCR amplification showed a high level of polymorphism through electrophoresis visualization. The PIC value identified the discrimination ability of a molecular marker depending on the number of alleles and the distribution of alleles so that it is equivalent to genetic diversity. PIC values ranged from 0 (monomorphic) to 1 (polymorphic or very discriminatory) (Chesnokov and Artemyeva 2015; Sornakili et al. 2017). The PIC value in this study based on eight RAPD primers showed a high value where all PIC values above 0.50 were expressed as informative PIC values (Botstein et al. 1980). Figure 3 shows that 22 sugarcane varieties were divided into two main clusters and 4 sub-clusters. Cluster 1 and 2 have a similarity of $34.6 \%$. The first sub-cluster had a $46.8 \%$ similarity value consisting of varieties of VMC 76-16, PSDK 923, TLH 2, BZ 132 which were samples from PG Madukismo Yogyakarta along with varieties of KK, Kentung, BL, and PSBM 901. The second sub-cluster has a $46.9 \%$ similarity consisting of varieties PSCO 902, PS 80.1649, PS 80,910, PS 951, PS 921, PS 891, and PS 881. The third sub-cluster has a $46.9 \%$ similarity value. This sub-cluster consisted of PS 865, PS 864, PS 862, PS 851, PS 384, and PS 58, while PS 41 varieties separate themselves from other sub-clusters and have a $37 \%$ similarity with three sub-clusters.

The results of this grouping can be understood through the relationship between varieties based on the origin of cultivation of the variety itself. All varieties studied were Indonesian superior varieties released by the Minister of Agriculture. Most of the varieties studied were derived from crosses carried out at P3GI (Indonesian Sugar Plantation Research Center), Pasuruan, East Java. The crosses from P3GI have a "PS" variety code. The first subcluster included eight varieties originated from development areas outside the P3GI Pasuruan area, except PSDK 923 and PSBM 901. The second sub-cluster consisted of seven varieties which were derived from crossing the P3GI Pasuruan. In this sub-cluster, the PS 951 and PS 921 varieties had the highest similarity index $(67.3 \%)$. The third sub-cluster included six varieties grouped into two subgroups. All varieties in these two groups were of P3GI Pasuruan crosses. In this sub-cluster, PS 851 and PS 384 varieties had the highest similarity $(59.6 \%)$. To maintain a high degree of diversity in a population is essential. This suggested that the varieties within the same cluster have low diversity and selection of parents between the group is considered promising for crop productivity development.

\section{ACKNOWLEDGEMENTS}

The authors are grateful for the funding support from The Ministry of Agriculture, Indonesian Agency for
Agricultural Research and Development through Cooperative Research, Assessment, and Development of Strategic Agriculture research grant in the fiscal year 2018, contract number: 2052/UN1/DITLIT/DIT-LIT/LT/2018. Special thanks also go to the research team in the Laboratory of Genetics and Breeding at Faculty of Biology, Universitas Gadjah Mada, Yogyakarta, Indonesia. We also appreciate the cooperation from Indonesian Sweetener and Fiber Crops Research Institute (ISFRI), Malang, Indonesia and Madukismo Sugar Factory, Yogyakarta, Indonesia.

\section{REFERENCES}

Anderson JA, Churchill GA, Autrique JE, Tanksley SD, Sorrels ME. 1993. Optimizing parental selection for genetic linkage maps. Genome 36: 181-187.

Botstein D, White RL, Davis RW. 1980. Construction of a genetic linkage map in man using restriction fragment length polymorphisms. Am J Hum Genet 32: 314-331.

Chesnokov YV, Artemyeva AM. 2015. Evaluation of the measure of polymorphism information of genetic diversity. Bioinformatics Math Stat 50 (5): $571-578$

Devarumath RM, Kawalde SB, Kawar PG, Sushir KV. 2012. Assessment of genetic diversity in sugarcane germplasm using ISSR and SSR markers. Sugar Tech 14 (1): 334-344.

Ekpelikpeze OS, Agre P, Dossou-Aminon I, AdjatinA, Dassou A, Dansi A. 2016. Characterization of sugarcane (Saccharum officinarum L.) cultivars of Republic of Benin. Int J Curr Res Biosci Plant Biol 3 (5): 147-156.

Ghane AA, Ghorpade BB, Fargade SA, Autade RA, Gaikwad DK, Chavan RS, Sarode DK. 2017. Molecular profiling and genetic diversity in sugarcane (Saccharum officinarum L.) genotypes using RAPD markers. Contemp Res India 7: 133-138.

James E. 2004. Crop Pests of Tanzania and Their Control. Edited by Federal Agency for Economic Cooperation. Paul Parly, Berlin.

M da Costa ML, Amorim LLB, Onofre LVC, de Melo LJOT, de Oliveira MBM, de Carvalho R, Benko-Iseppon AM. 2011. Assessment of genetic diversity in contrasting sugarcane varieties using Inter-Simple Sequence Repeat (ISSR) markers. Am J Plant Sci 2: 425-432.

McDaniel J, Pillai SD. 2002. Gel alignment and band scoring for DNA fingerprint using Adobe Photoshop. BioTechnique 32: 120-122.

Pandey A, Mishra RK, Misrah S, Singh YP, and Pathak S. 2011Assessment of genetic diversity among sugarcane cultivar (Saccharum officinarum L.) using simple sequence repeats. Online J Biol Sci 11: 105-111.

Sambrook J, Russel DW. 1989. Molecular Cloning: A Laboratory Manual 2nd ed. Cold-Spring Harbor Laboratory Press, New York.

Sornakili A, Rathinam PK, Thiruvengadum R, Kuppusamy P. 2017. Comparative assessment of RAPD and ISSR markers to study genetic polymorphism in Colletotrichum gloesoroides isolates of mango. Asian J Plant Pathol 11 (3): 130-138.

Subiyakto, Sulistyowati E, Heliayanto B, Purwati RD, Yulianti T, Djumali, Fatah GSA. 2016. Peningkatan Produktivitas Tebu untuk Mempercepat Swasembada Gula. IAARD Press, Jakarta.Ullah S M S, Hossain MA, Hossain MM, Barman S, Sohag MMH, Prodhan SH. 2013. Genetic diversity analysis of chewing sugarcane (Saccharum offcinarum L.) varieties by using RAPD markers. J Biosci Biotechnol 2 (2): 145- 150

Ullah SMS, Hossain MA, Hossain MM, Barman S, Sohag MMH, Prodhan S. 2013. Genetic diversity analysis of chewing sugarcane (Saccharum officinarum $\mathrm{L}$.) varieties by using RAPD markers. J Biosci Biotechnol 2 (2): 145-150.

William WW, Mackey K, Chomczynski P. 1997. Effect of pH and ionic strength on the spectrophotometric assessment of nucleic acid purity. BioTechnique 22: 474-481. 